\title{
THE TIMING OF THE POSTGLACIAL MARINE INVASION OF KAU BAY, HALMAHERA, INDONESIA
}

\author{
D M BARMAWIDJAJA*, A F M DE JONG**, \\ KLAAS VAN DER BORG**, W A VAN DER KAARS ${ }^{\dagger}$, \\ W J M VAN DER LINDEN ${ }^{*}$ \\ and \\ W J ZACHARIASSE ${ }^{\ddagger}$
}

\begin{abstract}
Kau Bay, Halmahera, Indonesia is a small marine basin that is separated from the adjacent SW Pacific Ocean by a shallow sill, 40m deep. Radiocarbon dating on piston cores in combination with a study on microfossils demonstrate that Kau Bay was a freshwater lake in combination with a study on microfossils demonstrate that Kau Bay was a fresthen ocean. If sill depth did not change in the intervening years, sea level at $10,000 \mathrm{BP}$ stood $40 \mathrm{~m}$ below the present level.
\end{abstract}

\section{INTRODUCTION}

Kau Bay, Halmahera, Indonesia is a small, 470m deep, pear-shaped basin separated from the deep southwest Pacific Ocean by a flat-floored, $30 \mathrm{~km}$ wide, $40 \mathrm{~m}$ deep sill (Fig 1). About 60 years ago, Kuenen (1943) already suggested that sediment cores taken from Kau Bay would reveal that freshwater conditions prevailed during glacial times, when sea level stood beneath sill depth. Unfortunately, he was unable to prove this idea because the cores he took in Kau Bay in 1930 during the Snellius I expedition failed to penetrate deep enough. Oceanographic observations made at the time, however, clearly showed that, below a depth of ca $350 \mathrm{~m}$, the bay waters were devoid of oxygen and had a high concentration of dissolved hydrogen sulphide (Van Riel, 1943).

\section{THE 1985 KAU BAY EXPEDITION, OBJECTIVES AND METHODS}

Kau Bay was visited again in April 1985 during the Snellius II expedition (Van der Linden et al, 1986). The main objectives set this time were to portray Late Quaternary bottom and surface water conditions and to study the changes in sediment and pore water chemistry to monitor mineral formation and (early) lithogenesis in this unique environment. We were also interested in testing Kuenen's hypothesis to learn whether, indeed, Kau Bay was a freshwater lake during glacial time and, if so, we would like to know at what time full marine conditions were restored. Further, if the elevation of the sill did not change appreciably in time, then the level of this barrier can be used to establish at what time sea level stood $40 \mathrm{~m}$ below the present level.

\footnotetext{
*Marine Geological Institute, Jalan Dr, Junjunan 236, PO Box 215 Bandung - 40174, Indonesia

***Robert J van de Graaff Laboratorium, Rijksuniversiteit Utrecht, PO Box 80.000, 3508 TA Utrecht,

The Netherlands

Hugo de Vries Laboratory, University of Amsterdam, Kruislaan 318, 1098 SM Amsterdam,

The Netherlands

*Werkgroep Mariene Aardwetenschappen, Institute of Earth Sciences Budapestlaan 4, PO Box 80.021, 3508 TA Utrecht, The Netherlands
} 


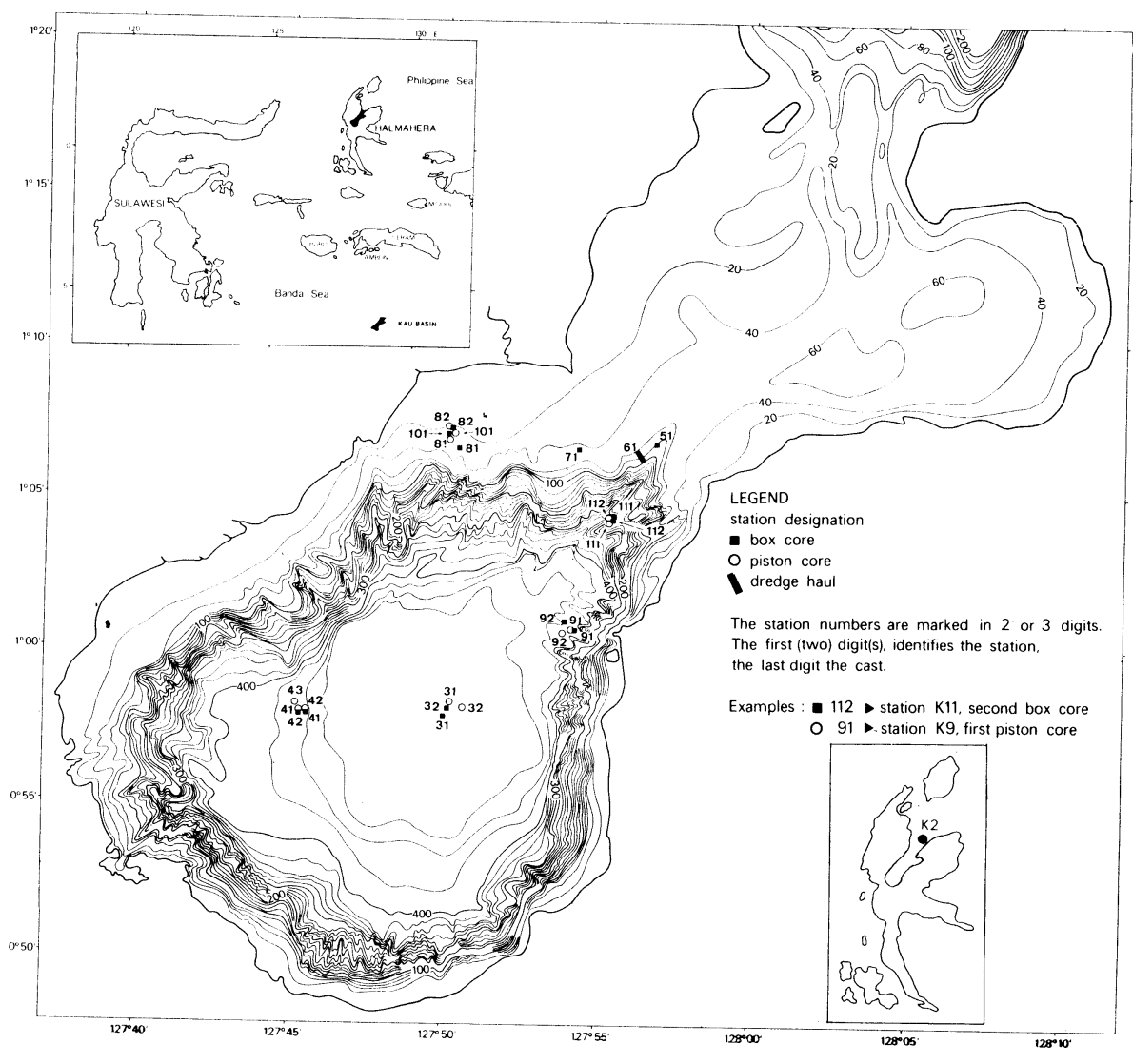

Fig 1. Bathymetry of Kau Bay and position of samples (after Van der Linden et al, 1986)

To tackle these problems, we occupied nine selected stations in Kau Bay where we recovered a total of 12 piston cores, 13 box cores and 1 dredge sample (Fig 1). At least two cores of $9 \mathrm{~cm}$ diameter per site were needed for subsequent analyses and reference. Cores were taken as much as possible from undisturbed sites as far as could be judged from $3.5 \mathrm{kHz}$ acoustic profiles.

\section{RADIOCARBON STRATIGRAPHY AND DEPOSITIONAL REGIME}

Cores $\mathrm{P} 1$ and $\mathrm{P} 3$ at station $\mathrm{K} 4$ bottomed into dark-colored dehydrated clays. The presence of a hard dolomitic layer within these clays appears to coincide with a distinct $3.5 \mathrm{kHz}$ acoustic reflector, $10-12 \mathrm{~m}$ below the basin floor (Van der Linden, Suharno \& Sukardjono, 1988). Other cores obviously did not penetrate deep enough to hit this salient lithological horizon. Apart from the dark-colored dehydrated clay and the dolomitic layer in cores $\mathrm{Pl}$ and $\mathrm{P} 3$ at station $\mathrm{K} 4$, there are no other lithological characteristics 
nor clear-cut (micro)faunal/floral events in the cores that enabled reliable time-stratigraphic correlations across Kau Bay. Also, the odd volcanic ash layer found in some cores cannot be traced basinwide.

Thus, to design a Late Quaternary time-stratigraphic framework, we relied heavily on accurate ${ }^{14} \mathrm{C}$ ages. We used the Utrecht Accelerator Mass Spectrometer (AMS) which requires only $1 \mathrm{mg}$ organic carbon for accurate

Table 1: Radiocarbon dates of samples from Kau Bay

\begin{tabular}{|c|c|c|c|c|}
\hline $\begin{array}{l}\text { Sample }^{a} \\
\text { name }\end{array}$ & $\begin{array}{l}\text { code no. } \\
\text { no }\end{array}$ & $\begin{array}{l}\text { Depth }^{c} \\
\text { (m) }\end{array}$ & $\begin{array}{r}\delta^{13 d} \\
(\% \circ \circ) \\
\end{array}$ & $\begin{array}{r}\text { Age }^{e} \\
\text { (yr BP) }\end{array}$ \\
\hline К3Р2\#9;26-28.5 & UtC-518 & 0.27 & -0.84 & $780(140)$ \\
\hline К3Р2\#8;52-54.5 & UtC-533 & 1.53 & -0.17 & $650(140)$ \\
\hline К3Р2\#4;56-58.5 & UtC-535 & 5.57 & -28.56 & $1180(90)$ \\
\hline K3P2\#3;64.5-67 & UtC-534 & 6.66 & 0.63 & $2340(140)$ \\
\hline К3Р2\#2;94.5-97 & UtC-481 & 7.95 & 0.39 & $1820(80)$ \\
\hline K3P2\#1;90-92.5 & UtC-517 & 8.91 & -1.34 & $1940(130)$ \\
\hline K4P3\#8;35-37.5 & UtC- 478 & 0.36 & -0.11 & $780(110)$ \\
\hline K4P3\#7;7.5-11 & UtC-47.5 & 0.74 & 0.38 & $1480(120)$ \\
\hline K4P3\#6;37-39 & UtC-480 & 2.03 & 0.75 & $2710(150)$ \\
\hline K4P3\#5;35.5-38 & UtC-476 & 3.03 & 0.14 & $3790(140)$ \\
\hline K4P3\#4;49.5-52 & UtC-474 & 4.17 & -1.17 & $5960(120)$ \\
\hline K4P3\#3;38-40.5 & UtC-479 & 5.05 & -0.40 & $7600(200)$ \\
\hline K4P3\#2;39-41.5 & UtC-472 & 6.06 & -4.18 & $9900(200)$ \\
\hline K4P3\#2;61.5-64 & UtC-477 & 6.29 & -4.06 & $9920(140)$ \\
\hline K4P3\#2;90-94.5 & UtC-473 & 6.59 & -4.04 & $9670(140)$ \\
\hline $\mathrm{K} 4 \mathrm{P} 1 \# 2 ; 12.5-15$ & UtC-646 & 7.66 & -2.93 & $9890(140)$ \\
\hline $\mathrm{K} 4 \mathrm{P} 1 \# 2 ; 17.5-20$ & $\mathrm{UtC}-647$ & 7.71 & -3.36 & $10030(140)$ \\
\hline K9P1\#6;0-4 & UtC-484 & 0.02 & -0.62 & $1300(110)$ \\
\hline К9P1\#5;24.5-27 & UtC-516 & 0.94 & -1.29 & $1270(80)$ \\
\hline K9P1\#5;94-96.5 & UtC-515 & 1.63 & -0.48 & $1560(90)$ \\
\hline K9P1\#4;44-46.5 & UtC-514 & 2.13 & -0.92 & $1570(150)$ \\
\hline К9P1\#3;86.5-89 & UtC-519 & 3.56 & -0.98 & $1450(100)$ \\
\hline К9P1\#2;51-53 & $\mathrm{UtC}-483$ & 4.20 & -0.02 & $1580(140)$ \\
\hline K9P1\#1;87.5-90 & UtC- 482 & 5.57 & -0.07 & $1970(130)$ \\
\hline $\mathrm{K} 11 \mathrm{P} 1 \# 6 ; 95-97.5$ & UtC-614 & 1.84 & 0.01 & $2530(110)$ \\
\hline $\mathrm{K} 11 \mathrm{P} 1 \# 5 ; 92.5-95$ & $\mathrm{UtC}-615$ & 2.92 & 0.15 & $4210(120)$ \\
\hline K11P1\#4;76.5-79 & UtC-616 & 3.76 & -0.16 & $5520(130)$ \\
\hline K11P1\#3;83-85.5 & $\mathrm{UtC}-617$ & 4.72 & -0.32 & $6260(90)$ \\
\hline $\mathrm{K} 11 \mathrm{P} 1 \# 2 ; 6.5-9$ & UtC-618 & 5.06 & -0.28 & $6410(110)$ \\
\hline $\mathrm{K} 11 \mathrm{P} 1 \# 1 ; 5-7.5$ & UtC-619 & 6.04 & -0.78 & $7610(140)$ \\
\hline
\end{tabular}

${ }^{a}$ Sample identification; material is calcite except for UtC-535 for which organic material has been used, as is also reflected by the $\delta^{13}$-value

${ }^{b}$ Code number of Van de Graaff Laboratorium, Rijksuniversiteit Utrecht, The Netherlands

${ }^{c}$ Depth below sea-floor

${ }^{d} \delta^{13}$-values measured at Earth Sciences Department, Rijksuniversiteit, Utrecht

${ }^{e}$ Age in years before present (BP) determined from measured ${ }^{14} \mathrm{C}$ activity by means of AMS 

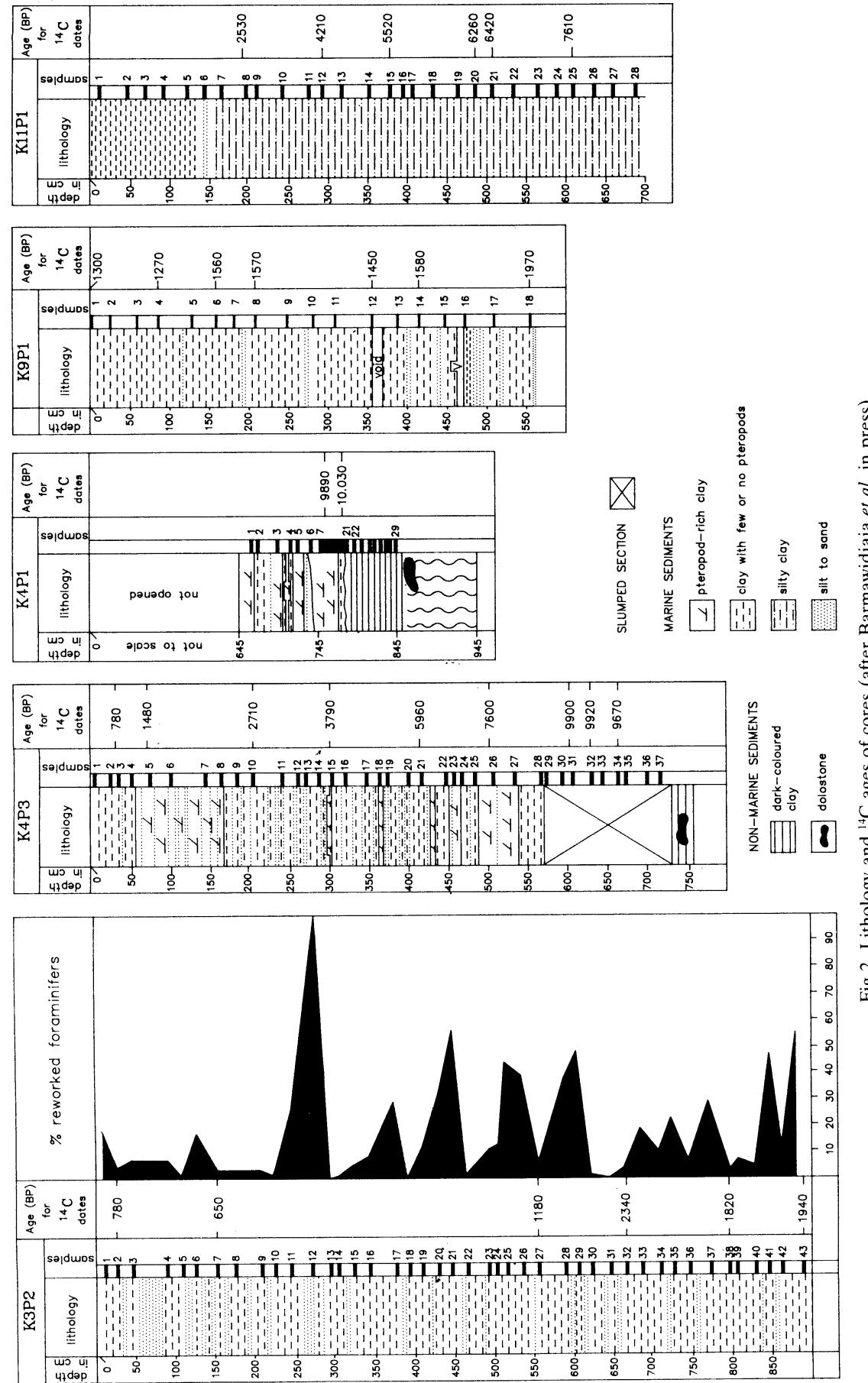
${ }^{14} \mathrm{C}$ determinations (Van der Borg et al, 1987). We obtained a $1 \mathrm{mg}$ sample of carbon from ca $10 \mathrm{mg}$ of biogenic carbonate derived from pteropods. Altogether, 30 levels of $2 \mathrm{~cm}$ thick dispersed over 5 piston cores were dated. Table 1 gives an overview of the Kau Bay ${ }^{14} \mathrm{C}$ ages and Figure 2 shows the lithology of the cores and their ${ }^{14} \mathrm{C}$ stratigraphy.

An important observation that can be made from Figure 2 is that the cores at stations K4 (down to $566 \mathrm{~cm}$ ) and K11 show a fairly consistent age progression with depth, while the ${ }^{14} \mathrm{C}$ chronology at stations $\mathrm{K} 3$ and $\mathrm{K} 9$ is thoroughly disturbed, even though the sediments at the latter stations are well stratified.

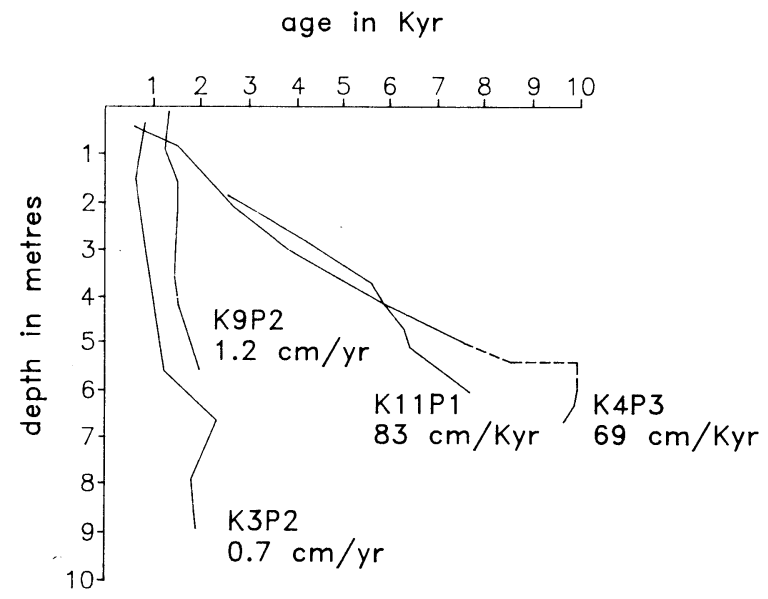

Fig 3. Sediment accumulation rates at stations K3, K4, K9 and K11 (after Barmawidjaja et al, in press)

Figure 3 shows that average sedimentation rates are high at stations $\mathrm{K} 3$ and $\mathrm{K} 9$ ( 0.7 and $1.2 \mathrm{~cm} / \mathrm{yr}$, respectively) and low at stations K4 and K11 (69 and $83 \mathrm{~cm} / \mathrm{kyr}$, respectively). Differences in sedimentation rate in the deepest basin are also observed in seismic reflection profiles (Van der Linden, Suharno \& Sukardjono, 1988), which show that station K4 is located at the top of a horst block with a tight sedimentary cover, whereas station $\mathrm{K} 3$ is located at the top of a down-faulted block with comparatively expanded sedimentary fill. Numerous turbidities and high percentages of reworked Pliocene planktonic foraminifera at station $\mathrm{K} 3$ indicate that large amounts of mass-transported sediments are trapped in the deepest part of Kau Bay. Station K9 is at the foot of a relatively steep slope and, thus, massive slumps of fine-grained slope sediments most likely contributed to the very high sedimentation rate. In contrast to this, large amounts of sediment may be expected to bypass station $\mathrm{K} 11$ which is somewhat isolated on a ledge (Van der Linden, Suharno \& Sukardjono, 1988).

\section{SEA LEVEL RISE AT PLEISTOCENE/HOLOCENE TIME}

The dark-colored dehydrated clay and associated dolomitic layer recovered at station $\mathrm{K} 4$ is rich in freshwater diatoms. The sole marine mi- 


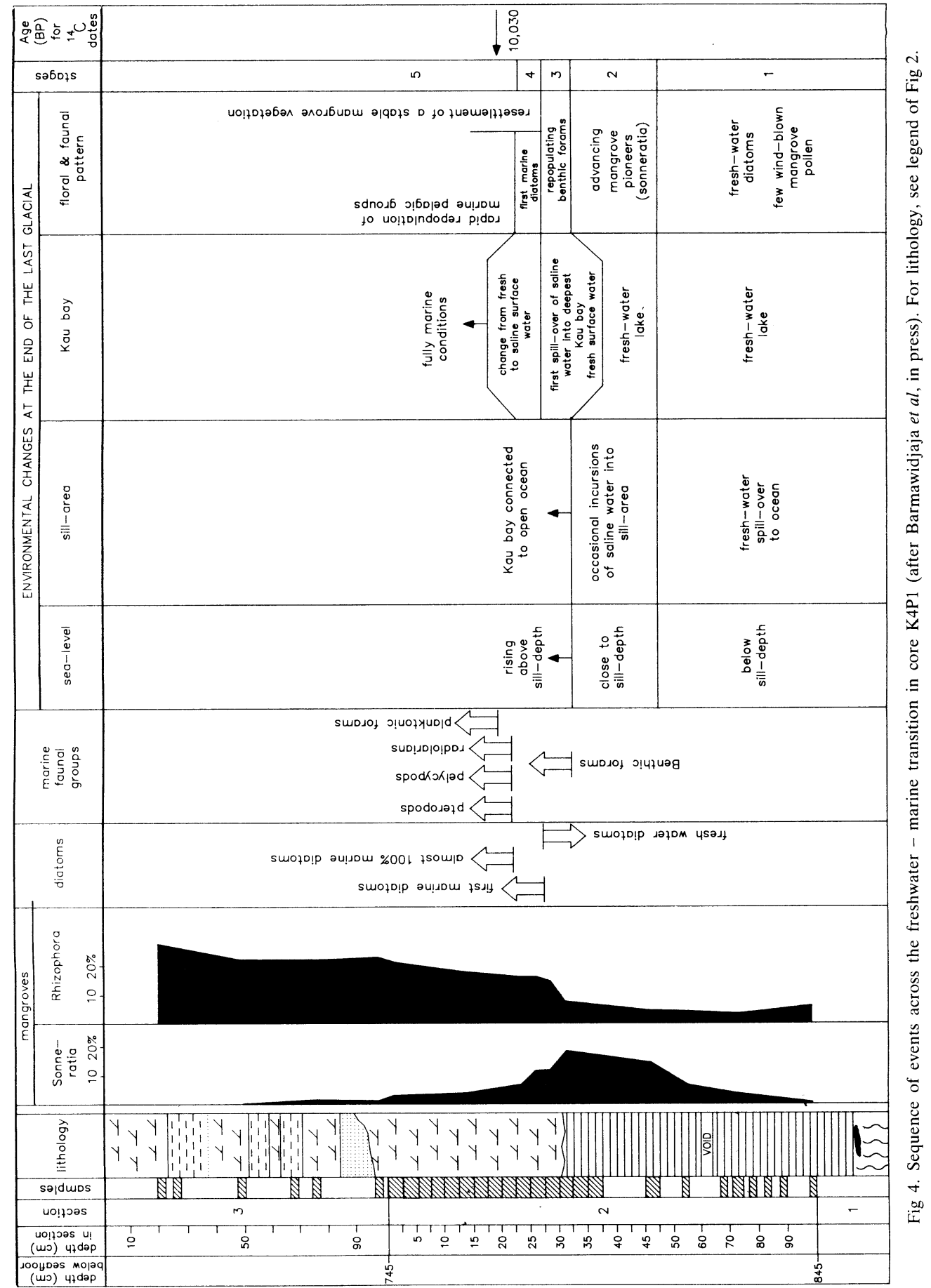



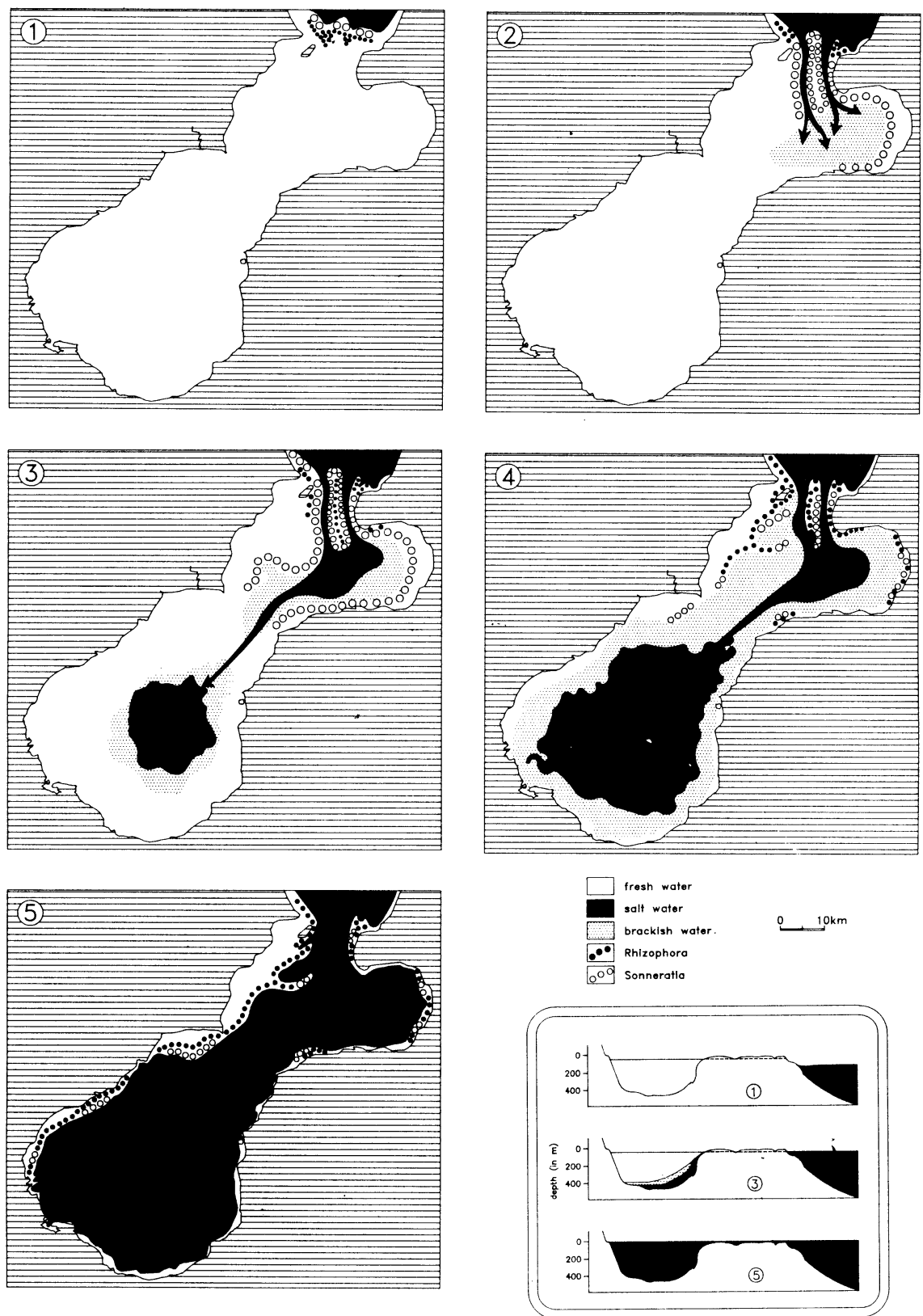

Fig 5. The Weichselian-Holocene marine invasion of Kau Bay in 5 (numbered) stages (after Barmawidjaja $e t a l$, in press). Explanation given in text. 
crofossils are a few mangrove pollen which most likely are blown in from the vicinity of Halmahera. The virtual absence of a mangrove vegetation in Kau Bay and the exclusive freshwater diatom flora indicate that the Bay at that time was a freshwater lake spilling over the sill into the ocean. In core P3, the changeover from lacustrine to marine conditions is disturbed by slumping between $566 \mathrm{~cm}$ and the dolomitic layer (Fig 3). Only core P1 provides an undisturbed section across the freshwater-marine transition (Fig 3). The sequence of biotic and environmental changes across the transitional interval of core P1 are given in Figure 4 and is the basis for Figure 5 in which the marine invasion of Kau Bay is illustrated in five successive stages.

During stage 1, Kau Bay was a freshwater lake, while sea level stood well below sill depth (Fig 5.1). Stage 2 is characterized by an increase in mangrove pioneers (represented by Sonneratia in Fig 4), suggesting the occasional inflow of saltwater through the deepest parts of the sill, ie, two (?) river valleys ( $c f$ Fig 1$)$, at times of exceptionally high tides and/or during storms. The exclusively freshwater diatom flora indicates that Kau Bay itself remained a freshwater lake (Fig 5.2). During Stage 3, benthic foraminifera invaded the deep water of the Bay (Fig 4), which demonstrates that saltwater started to spill over the sill and sink to the bottom. Surface waters, however, remained fresh since pelagic organisms exclusively consist of freshwater diatoms. At that time, Kau Bay became permanently reconnected with the open ocean (Fig 5.3). Surface waters changed from fresh to saline during Stage 4, as is evidenced by the first marine diatoms (Fig 4). At the same time, the pioneer mangrove was taken over by a stable vegetation (represented by Rhizophora in Fig 4) which rapidly expanded along the shores of Kau Bay (Fig 5.4). The invasion of pteropods, pelecypods and radiolarians into Kau Bay at the base of Stage 5 (Fig 4) indicates that full marine conditions were re-established at that time (Fig 5.5).

The earliest level permitting ${ }^{14} \mathrm{C}$ determination on biogenic carbonate is the base of Stage 5 and shows a ${ }^{14} \mathrm{C}$ age of 10,000 BP (Fig 4). Since this level is only $10 \mathrm{~cm}$ above the level at which Kau Bay becomes permanently reconnected with the open ocean (Fig 4) it seems justified to suppose that the time when sea level had risen to sill depth is close to 10,000 BP. If the elevation of the sill did not change appreciably since that time, which, at first seems unlikely, considering the local volcanic and seismic activity, then sea level at 10,000 BP stood $40 \mathrm{~m}$ below the present level. It is however, at least remarkable that this figure fits well to the Late Quaternary eustatic sea level curves of Curray (1965) and Oldale and O'Hara (1980) for the US east coast and is close to the Dillon and Oldale (1978) sea-level-rise curve for the same region. That it also fits the sea-level curve for the Huon Peninsula in nearby Papua, New Guinea (Chappell, 1983) adds rather more weight to our Kau Bay estimate.

Therefore, the age-calibrated sea-level mark for Kau Bay could be an important reference point in Late Quaternary sea-level history. 


\section{ACKNOWLEDGMENTS}

Work at sea was carried out during the Indonesian-Dutch Snellius II expedition under the auspices of the Netherlands Council of Oceanic Research (NRZ) and the Indonesian Institute of Sciences (LIPI).

\section{REFERENCES}

Barmawidjaja, DM, van der Borg, K, de Jong, AFM, van der Kaars, WA and Zachariasse, WJ, in press, Kau Bay, Halmahera, A Late Quaternary paleoenvironmental record of a poorly ventilated basin, in van Hinte JE, van Weering, TjCE and Fortuin, AR, eds, Internatl symposium on results of the Snellius II Expedition, Jakarta 1987, Proc: Netherlands Jour Sea Research.

Chappell, J, 1983, A revised sea-level record for the last 300,000 years from Papua New Guinea: Search, v 14, p 99-101.

Curray, JR, 1965, Late Quaternary history, continental shelves of the United States, in Wright, HE and Frey, DG, eds, The Quaternary of the United States: Princeton, New Jersey, Princeton Univ Press, p 723-735.

Dillon, WP and Oldale, RN, 1978, Late Quaternary sea-level curve: Reinterpretation based on glaciotectonic influence: Geology, v 6, p 56-60.

Kuenen, Ph, 1943, Collecting of the samples and some general aspects, Snellius Expedition, 19291930. vol 5, no. 3, p 1-46:Leiden, E J Brill.

Oldale, RN and O'Hara, C J, 1980, New radiocarbon dates from the inner continental shelf off southeastern Massachusetts and a local sea-level-rise curve for the past 12,000 yr: Geology, $\mathrm{v} 8, \mathrm{p} 102-106$.

Van der Borg, K, Alderliesten, C, Houston, CM, de Jong, AFM and van Zwol, NA, 1987, Accelerator Mass Spectrometry with ${ }^{14} \mathrm{C}$ and ${ }^{10} \mathrm{Be}$ in Utrecht: Nuclear Instr \& Methods, $\mathrm{v}$ B29, p 143.

Van der Linden, WJM, Hartosukohardjo, S, Zachariasse, WJ and de Lange, GJ, 1986, Theme 1, Geology and geophysics of the Banda Arc, Cruise G-4, Banda, Seram, Halmahera and Maluku Sea. Kau Bay April 14-April 29, 1985: Snellius II Expedition prog rept.

Van der Linden, WJM, Suharno, H and Sukardjono, H, in press, Kau Bay, Halmahera, regional setting, physiography and shallow structure, in van Hinte, JE, van Weering, TjCE and Fortuin, AR, eds, Internatl symposium on results of the Snellius II Expedition, Jakarta 1987, Proc: Netherlands Jour Sea Research.

Van Riel, PM, 1943, The bottom water, introductory remarks and oxygen content, Snellius Expedition 1929-1930, vol 2, no. 5, p 1-77: Leiden, E J Brill. 